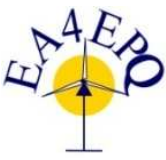

International Conference on Renewable Energies and Power Quality (ICREPQ'19) Tenerife (Spain), $10^{\text {th }}$ to $12^{\text {th }}$ April, 2019

Renewable Energy and OPourer Qualily. Sournal (RE\&PQJ)

ISSN 2172-038 X, No.17. July 2019

\title{
Wind Energy in Brazil: Current Overview and Projections on Power Generation
}

\author{
Fernando de Lima Camargo ${ }^{1 \text { e } 2}$, Nilcéia Cristina dos $\operatorname{Santos}^{1}$, Reinaldo Gomes da Silva ${ }^{1 \text { e } 2}$ \\ ${ }^{1}$ Faculdade de Tecnologia de Piracicaba “Dep. Roque Trevisan” (FATEC PIRACICABA) \\ CEETPS, Centro Estadual de Educação Tecnológica Paula Souza \\ Av. Diácono Jair de Oliveira, S/N, Piracicaba/SP (Brazil) \\ Phone number: +55 19 99614-1327 or +55 19 3411-2454 \\ E-mail: nilceia_santoss@yahoo.com.br,ncsantoss@hotmail.com \\ ${ }^{2}$ Escola de Engenharia de Piracicaba (EEP) \\ FUMEP, Fundação Municipal de Ensino de Piracicaba \\ Av. Monsenhor Martinho Salgot, 560, Piracicaba/SP (Brazil) \\ Phone number: +55 19 99602-1218 \\ E-mail: reinaldorgda@gmail.com,reinaldo@fumep.edu.br, flcamargo@fumep.edu.br
}

\begin{abstract}
National public policies contributed to the diffusion of wind energy in Brazil. The cost of production has been falling due to the infrastructure developed to meet the facilities required in the implementation of turbines that produce energy through the wind. Brazil has 534 wind farms with a total capacity of 13.4GW and the state of Rio Grande do Norte is the largest producer of this type of electricity, accounting for $27.7 \%$ of this amount. A justified strategy is the energy production of the winds during the dry season due to the supply of this source during this period, with the objective of preserving the reservoirs of the hydroelectric plants. The intermittency of the wind regime, the noise impact, the interference of the wind towers on the climate and the lack of research resources are some of the disadvantages that prevent the country from enjoying more of this inexhaustible source of energy.
\end{abstract}

Keywords: electric energy, sustainability, wind energy, economic impact.

\section{Introduction}

Energy demand grows in line with population growth, especially in developing countries, and the demographic concentration of certain regions calls for alternatives to meet these needs. Brazil does not have more water resources to meet its demand and currently uses other energy sources.
In 2001, due to the national electric power crisis, the government adopted energy policies to avoid such mishaps in the future (AQUILA, PERUCHI, ROTELA JR., ROCHA, QUEIROZ, PAMPLONA and BALESTRASSI, 2018) and incorporated new renewable and sustainable sources for his generation (JUÁREZ, ARAÚJO, ROHATGI and OLIVEIRA FILHO, 2014). The country's energy matrix was dominated by hydropower at the time. In Brazil, $75 \%$ of the electricity matrix is composed of renewable sources, consisting of hydropower, which generate $64 \%$ of the energy required by the country (MENDES and STHEL, 2018). In 2035 Brazil may have increased its share of renewable sources by $68 \%$ in its electric matrix (FREIRE, 2018).

Brazil is a major world producer of sugar and alcohol from sugar cane. With the waste generated in the process, it has carried out cogeneration and supplied electric power in localities close to the sugar and alcohol plants. Also as a strategy, it has imported natural gas from Bolivia and produced electricity using this fossil source. Thermoelectric plants provided $61.3 \%$ of the total installed capacity in Rio de Janeiro state in 2018, thermonuclear contributed $23.46 \%$ and only $14.86 \%$ came from hydroelectric plants (MENDES and STHEL, 2018). During the study period of Mendes and Sthel (2018), the average energy generated from thermoelectric plants was five times higher than those generated in hydroelectric plants. However in Brazil, the alternative that emplaced was the energy coming from the winds. Wind farms have no impact on the loss of biodiversity, floods such as those caused by the installation of hydroelectric plants and the displacement of local populations due to these ventures. 
Researchers point out that there is great potential to be explored in the electric generation with the increase of wind turbines, projected at six times the estimated potential in 2001 (AMARANTE; BROWER; ZACK and SÁ, 2001), which considered a tower height of $50 \mathrm{~m}$. There are currently towers over $100 \mathrm{~m}$ in the country. According to official government estimates, by 2025 Brazil will need an extra energy output of 200 TWh. Part of this energy could be produced by the winds, in coastal regions of the country, with an annual average of over 8.0 $\mathrm{m} / \mathrm{s}$ wind speed, measured at 50 meters high.

The objective of this paper is to present the Brazilian wind energy generation data, its participation in the country's energy matrix and question the existing facilities.

\section{LITERATURE REVIEW}

\subsection{Public Policies}

National public policies were essential for the recent development of the wind industry in the country (ADAMI, ANTUNES and SELLITTO, 2017). According to Freire (2018), from 2013 onwards, there was a review of auctions in the country that started to operate with specific sources to the detriment of the externalities of its facilities (Figure 1).

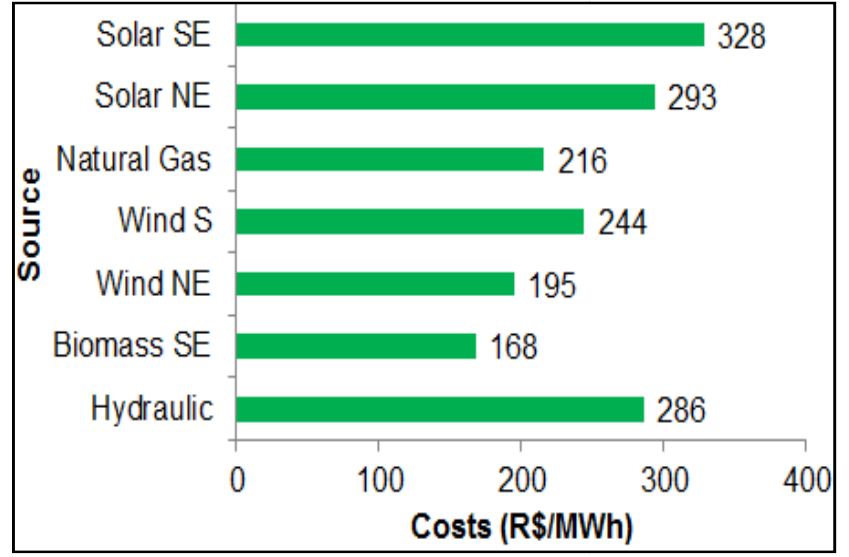

Figure 1: Sources and costs to produce electricity Source: (BORGES, 2018).

The Figure 1 shows the MWh production cost of several sources in several localities of the country. Hydroelectricity has become expensive due to the transmission lines linking production in remote locations to the final consumer. Biomass is the strategic source in the southeast region as far as wind is to the northeast.

The Figure 2 shows the installed capacity in each state of wind energy, which includes 534 parks with a total capacity of $13.4 \mathrm{GW}$, corresponding to $8.5 \%$ of the national energy matrix. The potential is three times higher than current production and grows at a rate of $20 \%$ per year (BORGES, 2018).

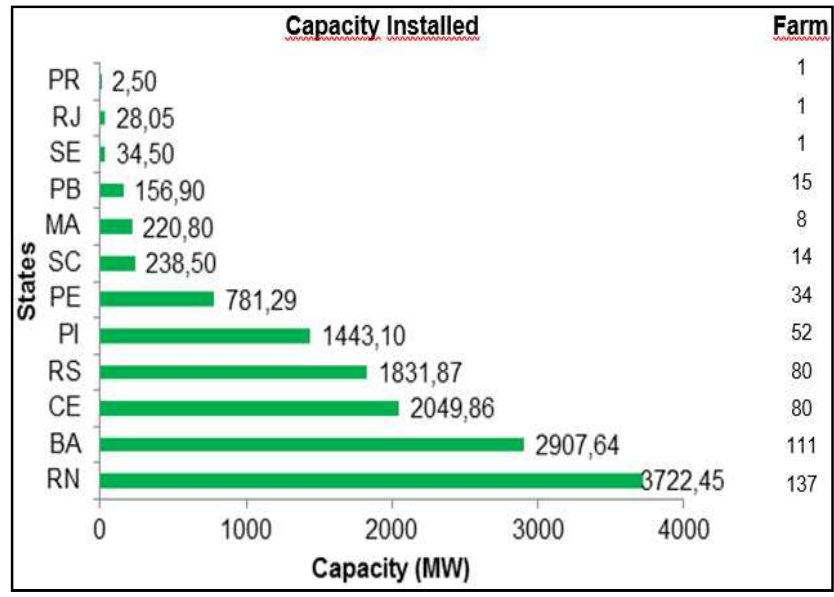

Figure 2: Wind energy participation in the national energy matrix

Source: (BORGES, 2018).

The Figure 2 shows that the largest producer of electricity from the winds was Rio Grande do Norte, which has 137 wind farms installed in the northeastern state. The southern region is led by Rio Grande do Sul, with a production of $1831 \mathrm{MW}$ in the 80 wind farms installed in the state.

\subsection{Wind Farms in Brazil}

The largest concentration of wind farms in Brazil is in the Northeast due to constant trade winds from the tropics to the equator. The origin of the wind is directly related to the differences of temperature in different regions of the terrestrial globe. The displacement of air from regions near the equator (warmer air) creates zones of low pressure; which are filled by colder air from the poles where high pressure regions exist (Figure 3).

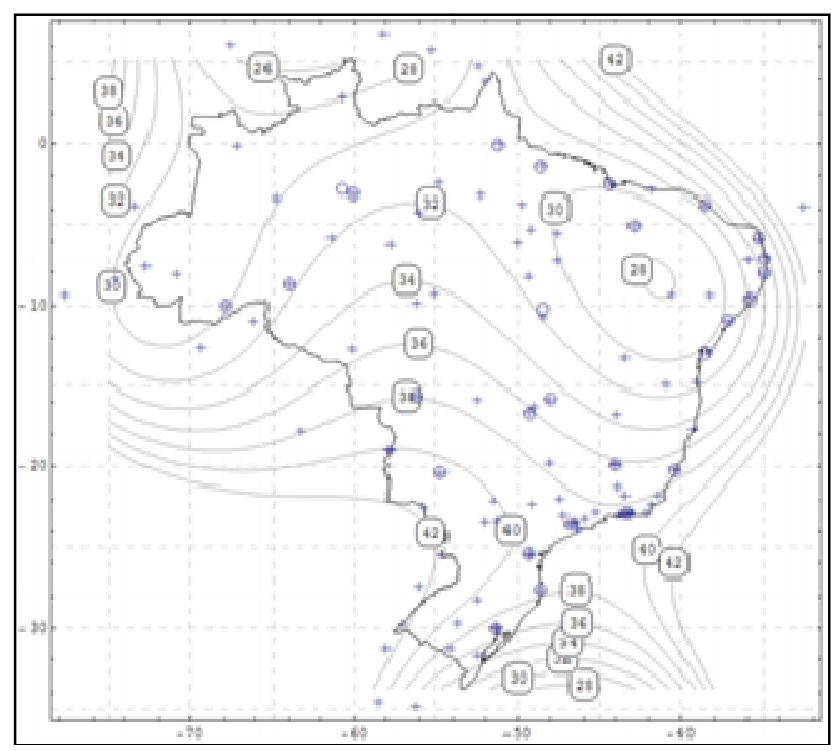

Figure 3: Wind speed on Brazil

Source: (BECK and CORRÊA, 2013). 
The main wind energy producers in the northeastern region of Brazil in February 2018 were: Rio Grande do Norte, with 3,722 MW and 137 wind farms; Bahia, with 2,907 MW and 100 wind farms; Ceará, with 2049 MW and 75 wind farms; Piauí, with 1,443 MW and 52 wind farms; Pernambuco, with $781 \mathrm{MW}$ and 34 wind farms; Maranhão, with $220 \mathrm{MW}$ and 8 wind farms; and Paraíba, with $157 \mathrm{MW}$ and 15 wind farms (Figure 4).

According to Áquila et al. (2018) the wind speed in the wind farms installed in Brazil varies between 6 and $12 \mathrm{~m} / \mathrm{s}$. In the Northeast region, the worst month in two of the three states evaluated by the authors was in April and in the South region was the month of May (Figure 4).

The southern region of the South American continent, on the other hand, has a favorable potential for the installation of large-scale wind farms. In South America, Brazil is the leader, in relation to installed capacity, of approximately $11 \mathrm{GW}$, whose value comprises $80 \%$. However, other countries have a greater wind potential than Brazil, and this resource is still unexplored in this continent (BANDOC, PRAVALIE, PATRICHE and DEGERATU, 2018). The main wind energy producers in southern Brazil in February 2018 were: Rio Grande do Sul, with 1,831 MW and 80 wind farms and Santa Catarina, with $238 \mathrm{MW}$ and 14 wind farms.

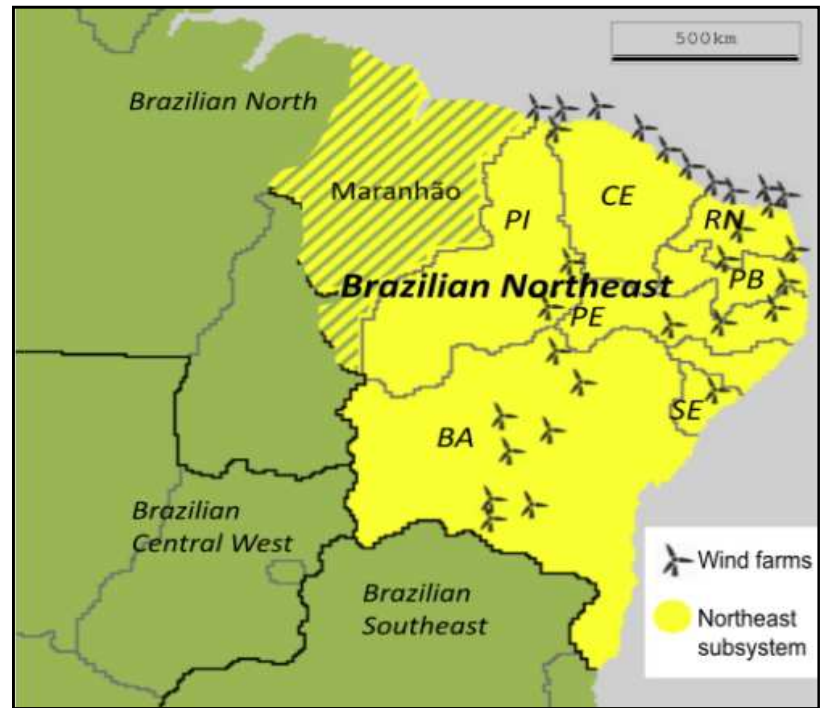

Figure 4: Wind energy in NE: Distribution of wind farms in the northeast region

Source: (JONG et al., 2017).

\subsection{Nominal Power (PN)}

Typically the turbine starts producing energy with a wind speed of around $5 \mathrm{~m} / \mathrm{s}$ and will reach a nominal power of $12 \mathrm{~m} / \mathrm{s}$. The height of the towers are fundamental to optimize wind energy capture, something above 150 meters high, but the country lacks cranes to make such installations (THRESHER, ROBINSON and VEERS, 2008). Wind power can be obtained by equation 1 .

$$
\mathrm{P}_{\mathrm{N}}=\frac{\pi}{8} \rho \mathrm{D}^{2} \mathrm{v}^{3}
$$
$\rho:$ air density (kg m-3)
D: rotor diameter $(\mathrm{m})$
$\mathrm{v}$ : air speed $(\mathrm{m} / \mathrm{s})$

A current wind turbine can present a tower height of $150 \mathrm{~m}$ and $160 \mathrm{~m}$ in diameter and $8 \mathrm{MW}$ of power (LEITE, ARAÚJO and ROSAS, 2018). The minimum wind speed at which electricity can be generated is called the cut-in speed, i.e. the speed at which the wind turbine rotor begins to rotate (Figure 5). The nominal output is usually obtained at the maximum speed that the rotor can rotate. Typically, wind turbine manufacturers place an upper limit on the speed that blades are allowed to increase blade longevity, preventing and minimizing bird impacts, rainfall, erosion etc. (LETCHER, 2017).

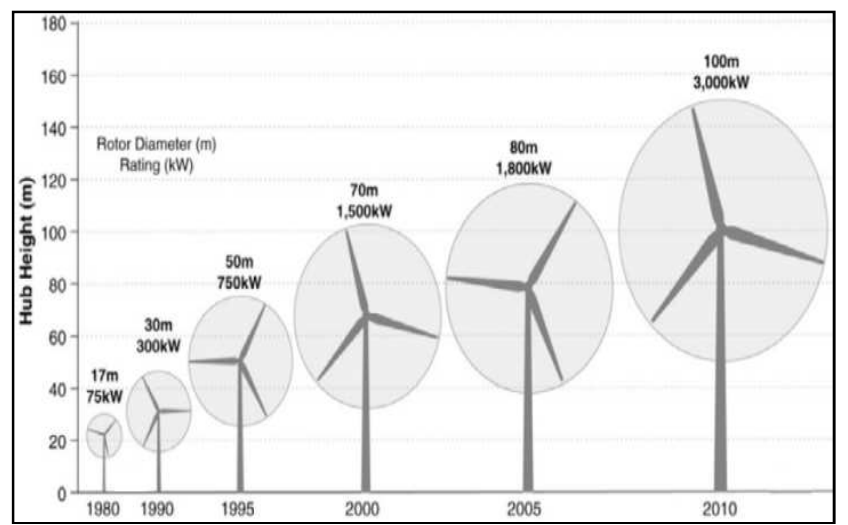

Figure 5: Typical increase of wind energy with height.

The load factor of a wind turbine, represented by equation 2, is the quotient between the annual net energy production $\mathrm{E}_{\mathrm{L}}$ and the energy that the turbine would theoretically produce if it operated constantly with its nominal power $\mathrm{P}_{\mathrm{N}}$ (maximum) during the 8760 hours of the year. The capacity factor of the installed wind farms studied was $38.1 \%$.

$$
\mathrm{FC}=\frac{\mathrm{E}_{\mathrm{L}}}{8760 \mathrm{P}_{\mathrm{N}}}
$$

It is precisely during the dry season, between the months of April and November, that the country uses wind energy in order to preserve the hydroelectric reservoirs (Figure 6).

P: Nominal Power (W) 


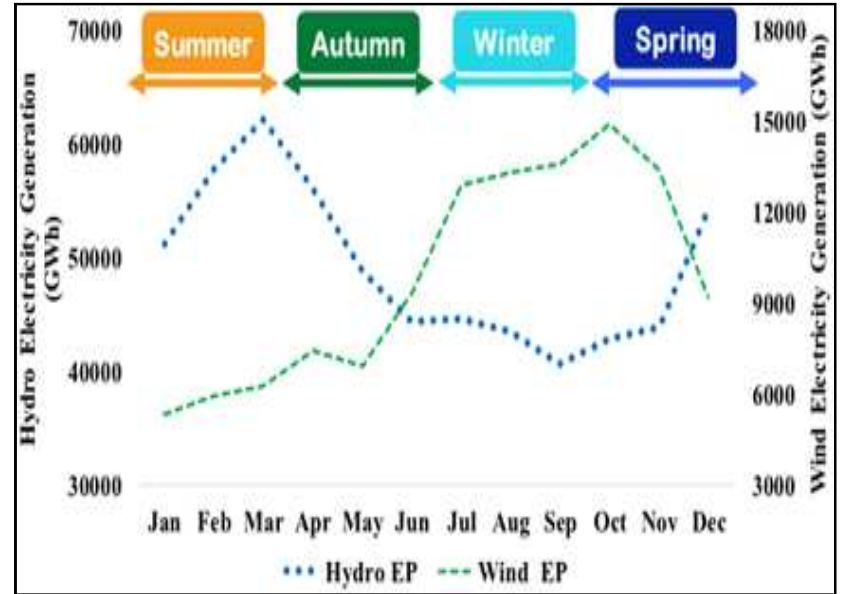

Figure 6: Relation between wind and hydro energies Source: (DRANKA and FERREIRA, 2018)

It was identified by REN et al (2018) that the intermittency in winter and spring is higher than in summer and fall in wind farms, which implies that the power output is more intermittent than wind speed. The intermittent scale of the wind farms is smaller than the scale of the wind turbine. The intermittence is more intense during the day than the night, being its highest value at noon.

\section{EVALUATION OF LITERATURE DATA}

The most significant impacts on wind farms were identified by Aquila et al. (2016) as the speed of the winds, the sale price of energy and the disbursement for investment. The latter, according to Letcher, (2017) was identified as the most serious disadvantage. It is for this reason that many governments around the world still offer subsidies for this technology.

\subsection{Wind Regime}

The intermittent winds are one of the major problems associated with the production of electricity in wind farms. The integration of this source, from large scale installations, has serious impacts on energy systems, such as reserves, reliability and cost. In addition, these impacts become more prominent with the increase in the level of penetration of wind energy (REN et al., 2017). The solution is to store the energy produced. Good locations for the use of wind energy are located in remote locations, implying in the transportation by high voltage cables the energy produced to the consumer. Another factor to consider is the need to deploy infrastructure and employee training for turbine support and maintenance (LETCHER, 2017).

\subsection{Maintaining and Increasing Power}

The basic and critical components of a wind tower are: gearbox, generator, main bearing, blades and tower. Among the critical components, wind turbine drive train components are subjected to highly dynamic loads due to the interaction of inertial forces, aerodynamic forces, elastic and structural forces, control forces and mechanical vibrations. The gearbox has received much attention due to its operational complexity and unit cost (LEITE, ARAÚJO and ROSAS, 2018).

Wind turbines that extrapolate their useful lives do not generate energy profitably due to maintenance costs. One of the major challenges is recycling of blades, as a viable method for large-scale recycling has yet to be found. The Palmas Wind Farm was studied, being the oldest in southern Brazil and approaching 20 years of operation, its expected useful life (MACHUCA, 2015).

\subsection{Environmental Impacts}

According to Miller and Keith (2018), wind energy can impact the climate by changing the atmospheric boundary layer. Wind turbines redistribute heat from the atmosphere due to the interaction between the equipment and the environment. The specific mass of the atmospheric air decreases, affecting the energy density, the wind velocity and the capacity factor in the wind park.

By converting the kinetic energy of the wind into electricity, wind turbines modify the exchange between the surface and the atmosphere and the transfer energy, momentum, mass, and moisture in the atmosphere. These changes can have striking impacts on climate and local and regional climate if wind farms are spatially large enough. However, studies for the impacts of wind energy on land surface changes are relatively new, and a better effort is needed to understand these impacts (WANG and WANG, 2015).

\section{FINAL CONSIDERATIONS}

Wind power is currently one of the most exploited resources in the world to produce electricity. Brazil needs to increase its production and will employ this resource to meet its demand.

The intermittence of the winds makes it difficult to integrate its energy production with the previously established continuous generation system, as is obtained in hydroelectricity. It will be a challenge to be overcome by the country.

Improving technology with more efficient and lower cost wind turbines will enable the country to reduce dependence on other, more polluting energy sources.

\section{REFERENCES}

[1] Adami, V. S.; Antunes Jr., J. A. V., Sellitto, M. A. Regional industrial policy in the wind energy sector: The case of the State of Rio Grande do Sul, Brazil. Energy Policy, n. 111, p. 18 - 27, 2017.

[2] AMARANTE; O. A. C.; BROWER, M.; ZACK, J. SÁ, A. L. Atlas do potencial eólico brasileiro. Brasília, 2001.

[3] Aquila, G.; Rocha, L. C. S.; Ritela Jr., P.; Pamplona, E. O.; Queiroz, A. R.; Paiva, A. P. Wind power generation: An 
impact analysis of incentive strategies for cleaner energy provision in Brazil. Journal of Cleaner Production, $n$. 137, p. 1100 - 1108, 2016.

[4] Aquila, G.; Peruchi, R. S.; Rotela Jr., P.; Rocha, L. C. S.; Queiroz, A. R.; Pamplona, E. O.; Balestrassi, P. P. Analysis of the wind average speed in different Brazilian states using the nested GR\&R measurement system. Measurement, 115, p. 217 - 222, 2018

[5] Bandoc, G.; Pravalie, R.; Patriche, C.; Degeratu, M. Spatial assessment of wind power potential at global scale. A geographical approach. Journal of Cleaner Production, n. 200, p. 1065 - 1086, 2018.

[6] Beck, A. T.; Corrêa, M. R. S. New Design Chart for Basic Wind Speeds in Brazil. Latin American Journal of Solids and Structures, n. 10, p. 707 - 723, 2013.

[7] Borges, A. Eólicas serão 2a. fonte de energia do País em 2019. O Estado de São Paulo, caderno Economia, p. B6 7, 5/08/2018.

[8] Dranka, G. G.; Ferreira, P. Planning for a renewable future in Brazilian power system. Energy, n. 164, p. 496 - 511, 2018.

[9] Freire, V. T. É possível elevar a fatia da energia limpa sem custo maior. Folha de São Paulo, caderno Mercado, p. A26-27, 21/10/2018.

[10] Gerelli, E. S. Análise dos dados anemométricos coletados pela creluz no município de Palmeira das Missões/RS para geração de energia elétrica por fonte eólica. Trabalho de Conclusão de Curso. Ijuí: UNIJUÍ, 2017.

[11] Jong, P.; Dargaville, R.; Silver, J.; Utembe, S.; Kiperstok, A.; Torres, E. A. Forecasting high proportions of wind energy supplying the Brazilian Northeast electricity grid. Applied Energy, n. 195, p. 538 - 555, 2017.

[12] Juárez, A. A.; Araújo, A. M.; Rohatgi, J. S.; Oliveira Fº, O. D. Q. Development of the wind power in Brazil: Political, social and technical issues. Renewable and Sustainable Energy Reviews, n. 39, p. 828 - 834, 2014.

[13] Letcher, T. M. Wind Energy Engineering: A handbook for onshore and offshore wind turbines. Elsevier, 2017.

[14] Leite, G. N. P.; Araújo, A. M.; Rosas, P. A. C. Prognostic techniques applied to maintenance of wind turbines: a concise and specific review. Renewable and Sustainable Energy Reviews, n. 81, p. 1947 - 1925, 2018.

[15] Machuca, M. N. Análise ambiental, técnica e econômica da pós-operação de parques eólicos. Trabalho de Conclusão de Curso. Florianópolis: UFSC, 2015.

[16] Mendes, L. F. R.; Sthel, M. S. Analysis of the hydrological cycle and its impacts on the sustainability of the electric matrix in the state of Rio de Janeiro/Brazil. Energy Strategy Reviews, n. 22, p. $119-126,2018$.

[17] Miller, L. M.; Keith, D. W. Climatic Impacts of Wind Power, Joule, n.2, p. 1 - 15, 2018.

[18] Ren, G.; Liu, J.; Wan, J.; Guo, Y.; Yu, D. Overview of wind power intermittency: Impacts, measurements, and mitigation solutions. Applied Energy, n. 204, p. 47 - 65, 2017.

[19] Ren, G.; Wan, J.; Liu, J.; Yu, D.; Soder, L. Analysis of wind power intermittency based on historical wind power data. Energy, 50, p. 482 - 492, 2018.

[20] Thresher, R.; Robinson, M. Veers, P. Wind Energy Technology: Current Status and R\&D Future. Conference Paper NREL/CP-500-43374 August 2008.

[21] Wang, S.; Wang, S. Impacts of wind energy on environment: A review. Renewable and Sustainable Energy Reviews, n. 49, p. 437 - 443, 2015. 